\title{
Pengelolaan Pendidik dan Tenaga Kependidikan di SMA Muhammadiyah Kendari
}

\author{
Syahrul $^{1} \&$ Nurmayanti ${ }^{2}$ \\ ${ }^{1}$ Fakultas Tarbiyah dan Ilmu Keguruan IAIN Kendari \\ email: syahrul.stain@gmail.com \\ ${ }^{2}$ Fakultas Tarbiyah dan Ilmu Keguruan IAIN Kendari \\ email: ny2074686@gmail.com
}

\begin{abstract}
Abstrak
Artikel ini bertujuan menjelaskan beberapa aspek terkait pengelolaan guru dan tenaga kependidikan di SMA Muhammadiyah Kendari, yang meliputi: 1) perencanaan guru dan tenaga kependidikan di SMA Muhammadiyah Kendari; 2) pengorganisasian guru dan tenaga kependidikan di SMA Muhammadiyah Kendari; 3) memotivasi guru dan tenaga kependidikan di SMA Muhammadiyah Kendari; 4) pengawasan guru dan tenaga kependidikan di SMA Muhammadiyah Kendari. Penelitian dilakukan dengan menggunakan pendekatan kualitatif-deskriptif. Proses pengumpulan data dilakukan melalui wawancara, observasi, dan studi dokumentasi. Analisis data dilakukan melalui proses reduksi, display, dan verifikasi. Jaminan keabasahan dan kehandalan data diperoleh melalui perpanjangan pengamatan, peningkatan ketekunan dan proses trianggulasi. Hasil penelitian menunjukkan bahwa perencanaan guru dan tenaga kependidikan dilakukan melalui proses analisis kebutuhan yang melibatkan majelis pendidikan dasar dan menengah, serta komite sekolah. Pengorganisasian guru dan tenaga kependidikan adalah penempatan para guru dan tenaga kependidikan yang telah terpilih dari proses penerimaan sesuai dengan bidang masing-masing. Proses memotivasi guru dan tenaga kependidikan tidak hanya dilakukan secara verbal tetapi juga dalam bentuk teladan langsung dari kepala sekolah. Adapun pengawasan guru dan tenaga kependidikan dilakukan dalam bentuk administratif dengan menggunakan instrumen monitoring, selain itu melalui kunjungan kelas.
\end{abstract}

Kata Kunci: Pengelolaan, Guru, Tenaga Kependidikan, Standar Mutu 
Teacher Management and Education Personnel at Muhammadiyah High School of Kendari

\author{
Syahrul $^{1} \&$ Nurmayanti ${ }^{2}$ \\ ${ }^{1}$ Fakultas Tarbiyah dan Ilmu Keguruan IAIN Kendari \\ email: syahrul.stain@gmail.com \\ ${ }^{2}$ Fakultas Tarbiyah dan Ilmu Keguruan IAIN Kendari \\ email: ny2074686@gmail.com
}

\begin{abstract}
This article aims to explain several aspects related to the management of teachers and education staff in Kendari Muhammadiyah High School, which include: 1) teacher and education staff planning in Kendari Muhammadiyah High School; 2) the organization of teachers and education staff in Muhammadiyah High School Kendari; 3) motivating teachers and education personnel in Muhammadiyah Kendari High School; 4) supervision of teachers and education personnel in SMA Muhammadiyah Kendari. The study was conducted using a qualitative-descriptive approach. The process of collecting data is done through interviews, observations, and documentation studies. Data analysis is performed through the process of reduction, display, and verification. Data security and reliability are obtained through extended observation, increased perseverance and triangulation processes. The results showed that the planning of teachers and education personnel was carried out through a needs analysis process involving primary and secondary education assemblies, as well as school committees. Organizing teachers and education personnel is the placement of teachers and education personnel who have been selected from the admission process in accordance with their respective fields. The process of motivating teachers and education personnel is not only done verbally but also in the form of direct examples from the principal. The supervision of teachers and education personnel is carried out in an administrative form using monitoring instruments, in addition to through class visits.
\end{abstract}

\title{
Keywords: Management, Teachers, Educational Personnel,
} Quality Standards 


\section{Pendahuluan}

Guru dan tenaga kependidikan merupakan komponen penting dalam penyelenggaraan sekolah ${ }^{1}$. Kelangsungan pembelajaran yang berkualitas sangat ditentukan oleh keberadaan guru yang berkualitas pula $^{2}$. Indikator kualitas guru dapat dilihat dari segi kompetensinya, minimal dalam empat aspek, yaitu: kepribadian, profesional, sosial, dan pedagogik ${ }^{3}$. Penguasaan keempat aspek tersebut dapat menjadi modal minimal untuk terjadinya interaksi pembelajaran berkualitas.

Tenaga kependidikan tidak dapat dikesampingkan dalam penyelenggaraan sekolah, sehingga menjadi salah satu standar penilaian sebuah sekolah ${ }^{4}$. Mereka menjadi pilar utama pengelolaan sekolah secara keseluruhan. Tidak hanya pada aspek administratif, tetapi juga perlu dilibatkan dalam pengambilan keputusan-keputusan strategis. Pengalaman berbagai sekolah menunjukkan bahwa peran serta secara aktif tenaga kependidikan dapat menjadi faktor penting dalam kemajuan sekolah ${ }^{5}$.

Karenanya diperlukan pengelolaan yang baik terhadap kedua entitas di atas. Kepala sekolah memegang peran penting dalam tugastugas pemberdayaan guru dan tenaga kependidikan ${ }^{6}$. Dalam konteks inilah, SMA Muhammadiyah menarik untuk diperhatikan, sebagai salah satu sekolah di Kota Kendari dengan pengelolaan baik. Predikat akreditasi A pada sekolah ini dapat menjadi indikator bahwa berbagai aspek telah terkelola sesuai standar. Artikel ini berupaya

1 Setiyati, S. (2014). Pengaruh kepemimpinan kepala sekolah, motivasi Kerja, dan budaya sekolah terhadap kinerja guru. Jurnal Pendidikan Teknologi dan Kejuruan, 22(2), 200-206.

${ }^{2}$ Hendri, E. (2010). Guru berkualitas: profesional dan cerdas emosi. Jurnal saung guru, 1(2), 1 .

${ }^{3}$ Fahdini, R., Mulyadi, E., Suhandani, D., \& Julia, J. (2014). Identifikasi Kompetensi Guru sebagai Cerminan Profesionalisme Tenaga Pendidik di Kabupaten Sumedang. Mimbar Sekolah Dasar, 1(1), 33-42.

${ }^{4}$ Bachtiar, M. Y. (2016). Pendidik dan Tenaga Kependidikan. Publikasi Pendidikan, 6(3).

5 Surya, P. (2012). Peran penting tenaga administrasi sekolah dalam penguatan budaya sekolah untuk implementasi pendidikan karakter. Online),(staffnew. uny. ac. id/upload/198111112009121001/penelitian/makalah+ $I K A+$ 2012. $p d f)$.

6 Baharun, H. (2018). Peningkatan kompetensi guru melalui sistem kepemimpinan kepala madrasah. At-Tajdid: Jurnal Ilmu Tarbiyah, 6(1), 1-26. 
menggambarkan pengelolaan guru dan tenaga kependidikan di SMA Muhammadiyah Kendari.

\section{Metode dan Bahan}

Penelitian ini merupakan penelitian kualitatif yaitu metode yang menitik beratkan pada penalaran yang berdasarkan realitas sosial secara objektif. Dengan demikian penelitian ini berupaya mengumpulkan data-data atau informasi obyektif di lapangan mengenai pengelolaan guru dan tenaga kependidikan di SMA Muhammadiyah Kendari, dan kemudian ditelaah, dikaji dan diolah secara deskriptif kualitatif. Pengelolaan guru dan tenaga kependidikan merupakan situasi sosial yang mencakup pelaku (actor), tempat (place), dan kegiatan (activity) ${ }^{7}$.

Data yang terkumpul adalah data kualitatif berupa pernyataanpernyataan atau penjelasan-penjelasan bukan berupa angka-angka, yang terbagi dalam kategori primer dan sekunder. Langkah utama yang dilakukan untuk mendapatkan data yang dibutuhkan adalah menetapkan informan kunci (key informan) ${ }^{8}$, sebagai pintu masuk untuk mendapatkan informasi yang lebih luas. Informan kunci terpilih adalah kepala sekolah SMA Muhammadiyah Kendari.

Untuk mengumpulkan data dalam penelitian ini digunakan teknik yaitu Field research yakni mengumpulkan data langsung dilapangan. Pada metode ini, peneliti menggunakan cara sebagai berikut:

a. Observasi (pengamatan) yaitu "mengalami peristiwa pengelolaan guru dan tenaga kependidikan di SMA Muhammadiyah Kendari secara utuh, melalui penginderaan oleh peneliti”. Dalam penelitian ini, peneliti akan mengamati lebih mendalam tentang Kinerja Kepala Sekolah di SMA Muhammadiyah Kendari kecamatan Wuawua kota kendari provensi Sulawesi tenggara.

b. Interview (wawancara) yaitu "suatu bentuk komunikasi verbal, jadi semacam percakapan yang bertujuan memperoleh informasi”. Cara ini ditempuh dengan model diskusi ataupun tanya jawab, yang

7 Burhan, B. (2007). Penelitian Kualitatif: Komunikasi, Ekonomi, Kebijakan Publik, dan Ilmu Sosial Lainnya. Jakarta: Prenada Media Group.

${ }^{8}$ Moleong, J. Lexy. 2014, Metodologi Penelitian Kualitatif, Bandung: PT. Remaja Rosdakarya. 
selanjutnya dikembangkan secara bertahap hingga mendalam, terstruktur maupun tidak terstruktur ${ }^{9}$.

c. Dokumentasi yaitu proses mengumpulkan data dengan mengadakan pencatatan terhadap data untuk memperoleh data sekunder yang meliputi profil madrasah/sekolah, jumlah pendidik dan tenaga kependidikan, jumlah siswa, serta dokumen dan hal-hal lain yang dibutuhkan dalam penelitian ini $^{10}$.

Adapun tehnik analisis data dilakukan melalui tahap reduksi, display dan verifikasi, yang selengkapnya dijelaskan sebagai berikut:

a. Reduksi data (data reduction), mereduksi data berarti merangkum, memilih hal-hal yang pokok dan memfokuskan pada hal-hal yang penting, serta dicari teman dan polanya. Sehingga data yang telag direduksi akan menunjukkan gambaran yang jelas dan mempermudah peneliti.

b. Penyajian data (data display), dilakukan penelahan pada seluruh data yang ada dari berbagai sumber yaitu wawancara, observasi, maupun data dokumentasi yang telah diperoleh untuk menjadi bahan dalam melakukan analisis dalam bentuk uraian singkat, bagan hubungan antara kategori flowchart dan sejenisnya.

c. Conclusion Drawing/verification merupakan penarikan kesimpulan dan verifikasi. Kesimpulan awal, didukung oleh bukti-bukti yang kuat mendukung pada tahap pengumpulan data berikutnya. Tetapi "apabila kesimpulan yang dikemukakan pada tahap awal, didukung oleh bukti-bukti yang valid dan konsisten saat mengumpulkan data maka kesimpulan yang dikemukakan merupakan kesimpulan yang kredibel" "1.

Guna memperoleh kesimpulan yang tepat dan obyektif diperlukan kredibilitas data yang bermaksud untuk membuktikan bahwa apa yang berhasil dikumpulkan sesuai dengan apa yang terjadi. Adapun pengecekan keabsahan data dilkukan melalui "perpanjangan pengamatan, meningkatkan ketekunan dalam penelitian, triangulasi, dan member check",

${ }^{9}$ Gunawan, I. (2013). Metode penelitian kualitatif. Jakarta: Bumi Aksara.

10 Sukmadinata, S. N. (2005). Metode Penelitia. Bandung: PT Remaja Rosdakarya.

${ }^{11}$ Sugiyono. (2008). Metode penelitian pendidikan:(pendekatan kuantitatif, kualitatif dan $R \& D)$. Alfabeta.

${ }^{12}$ Ibid,.. h.121. 


\section{Hasil Penelitian dan Pembahasan}

\section{Hasil Penelitian}

\section{A. Perencanaan Guru dan Tenaga Kependidikan}

Secara teori bahwa kegiatan perencanaan dalam pendidikan itu ditentukan oleh cara, sifat, dan proses pengambilan keputusan, sehingga nampaknya dalam hal ini terdapat banyak komponen yang ikut memproses. Pada kegiatan penentuan kebijakan sampai kepada pelaksanaan perencanaan pendidikan ada beberapa garis besar yang perlu diperhatikan, yaitu: siapa yang memegang kekuasaan, siapa yang menentukan keputusan, dan faktor-faktor apa saja yang perlu diperhatikan dalam pengambilan keputusan. Terutama dalam hal pemegang kekuasaan sebagai sumber lahirnya keputusan, perlu memperoleh perhatian, misalnya pada lembaga pendidikan yaitu menganalisa bagaimana dan kepada siapa dibebankan tugas-tugas yang terkandung dalam kebijakan tersebut.

Proses perencanaan pendidikan yang efektif dan efisien secara mutlak harus ditopang oleh analisa yang matang. Analisa yang dibutuhkan yaitu bidang kebijakan intern pendidikan. Pelaksanakan analisa kebijakan di sekolah dapat dilaksanakan oleh stake holder yang berperan penting melalui kegiatan rapat di SMA Muhammadiyah Kendari. Terbukti sebelum melakukan kegiatan dan menetapkan suatu program dibuat analisa yang sematang mungkin. Hal itu sebagaimana hasil wawancara dengan Kepala Sekolah yaitu:

Sebelum menetapkan rencana kerja kedepan maka terlebih dahulu melakukan analisis. Analisis ini dilakukan ketika kami mengadakan rapat, pada rapat tersebut kami menentukan program-program apa yang layak menjadi prioritas dengan menganalisis faktor keuangan dan kesempatan. ${ }^{13}$

Berdasarkan pernyataan di atas dapat disimpulkan bahwa SMA Muhammadiyah Kendari dalam melakukan pengembangan guru dan staf melakukan perencanaan terlebih dahulu. Bahkan di dalam sebuah perencanaan dilakukan analisis yang akurat sehingga program perencanaan yang dibuat sebaik mungkin. Adapun program pelaksanaan perencanaan dibahas dalam rapat. Pernyataan ini sejalan dengan pernyataan informan sebagai berikut:

Dalam pelaksanaan perencanaan dibahas dalam rapat, dan dalam rapat tersebut membicarakan tentang program yang akan

${ }^{13}$ Taslim, (Kepala Sekolah), Wawancara, 26 Juli 2018 
dilakukan oleh guru dan staf, misalnya penentuan jadwal mata pelajaran, penentuan kurikulum yang akan digunakan, penentuan penyiapan bahan ajar dan perencanaan kegiatan pengembangan pedagogic guru dan staf. ${ }^{14}$

Dari pernyataan di atas, dapat disimpulkan bahwa SMA Muhammadiyah Kendari dalam rapat dilakukan untuk membicarakan masalah yang berkaitan dengan kegiatan pengajaran, seperti, penentuan jadwal mata pelajaran, penentuan beban jam belajar, menentukan bahan ajar yang akan digunakan dan menentukan kurikulum yang akan diaplikasikan serta pengembangan pedagogic guru dan keterampilan staf.

\section{B. Pengorganisasian Guru dan Tenaga Kependidikan}

Pengorganisasian merupakan kegiatan pengelompokkan setiap wewenang atau pembagian tugas (job discription) setiap guru dan staf. Sekolah harus mampu memilah-milah setiap pekerjaan sesuai dengan kapasitas masing-masing unsur. Seorang guru yang profesional maka harus melaksanakan tugas sesuai dengan ilmu yang dimilikinya. Begitu pula tenaga staf sekolah, harus menjalankan tugas sesuai dengan skill yang dimilikinya.

Di SMA Muhammadiyah Kendari dalam pengelolaanya selalu memperhatikan pelaksanaan pengorganisasian. Hal itu dilakukan agar program kerja yang dibuat dapat terealisasi secara menyeluruh. Sebagaimana hasil wawancara dengan kepala sekolah yaitu:

Jadi untuk merealisasikan sebuah perencanaan di sekolah ini kami melakukan pengorganisasian. Jika yang menjadi bahasan disini guru dan staf maka sesungguhnya yang diorganisasikan berkaitan dengan kegiatan belajar mengajar dan pengelolaan administrasi sekolah. Untuk meningkatkan kapasitas guru dalam mengelola proses belajar mengajar di sekolah dan kapasitas keterampilan staf dalam menjalankan administrasi sekolah kami selalu memberikan kesempatan kepada setiap guru dan staf untuk mengikuti diklat, workshop, dan studi lanjut ${ }^{15}$.

Berdasarkan pernyataan di atas, tentunya untuk meningkatkan kualitas pendidikan di sekolah ini, pihak yang berwenang melakukan

\footnotetext{
${ }^{14}$ Nuraini, (Bendahara), Wawancara,

${ }^{15}$ Taslim, (Kepala Sekolah), Wawancara, 26 Juli 2018
} 
pengorganisasian adalah keterampilan melakukan kegiatan belajar mengajar sedangkan untuk staf yang ditingkatkan adalah keterampilan mengelola administrasi dan mengelola saran kependidikan seperti laboratorim.

Setiap kegiatan pengorganisasian di sekolah ini dilakukan sebagaimana mestinya. Hasil temuan di lapangan diketahui bahwa kegiatan pengorganisasian dapat terlaksana dengan baik, dapat dilihat melalui kegiatan rapat pembagian tugas dan pengorgainsasian kompetensi guru. Dimana pada rapat tersebut telah dibentuk team penyusun jadwal pembelajaran. Kemudian satu minggu setelah rapat diputuskan jadwal telah dirampungkan oleh team yang dipimpin waka kurikulum. Tentunya sebelum ditetapkan jadwal, maka ada kesepakatan tentang mata pelajaran dan jam yang akan diajarkan. Hal ini juga diperkuat dengan hasil wawancara dengan kepala sekolah yaitu:

Sebagai seorang pemimpin saya harus mengundang seluruh guru untuk duduk bersama membicarakan pelaksanaan pembelajaran yang akan dilakukan. Salah satu bentuk pengorganisasian di sekolah ini yaitu melalui rapat pembagian tugas ${ }^{16}$.

Agar sistem pembelajaran berjalan lancar maka perlu pengelompokan kemampuan dan keterampilan guru sesuai bidangnya masing-masing. Selain bertujuan untuk mudah mengontrol kinerja guru dengan pembagian tugas juga dapat memetakan kemampuan berdasarkan tingkatan kesarjanahan. Jika pengorganisasian ini dilaksanakan dengan baik dan benar maka tujuan pembelajaran mudah untuk diwujudkan. Adapun prosesnya dengan mengundang guru untuk hadir dalam rapat pembagian tugas, peserta rapat adalah guru. Secara bersama-sama guru mengajukan usul dan saran terhadap mata pelajaran dan pengajarnya. Tentunya dalam memutuskan hasil rapat melaui pertimbangan saran guru dan analisis yang panjang.

\section{Memotivasi Guru dan Tenaga Kependidikan}

Motivasi merupakan bentuk upaya meningkatkan semangat kerja bawahan. Secara teoritis motivasi itu ada yang timbul dari dalam dan dari luar individu. Untuk mencapai keberhasilan dalam lembaga pendidikan motivasi sangat penting dilakukan sebab dengan motivasi

${ }^{16}$ Taslim, (kepala sekolah), Wawancara, 26 Juli 2018 
akan memberikan spirit kepada guru dan staf. Pemberian motivasi dapat dilakukan dalam bentuk materi dan sanjungan.

Di SMA Muhammadiyah Kendari juga selalu memberikan motivasi kepada seluruh guru dan staf. Hal itu sebagaimana dijelaskan oleh wakil kepala sekolah yaitu:

Di sekolah ini, stakeholder selalu meberikan apresiasi bagi guru dan staf yang memiliki prestasi kerja, meskipun untuk saat ini belum dalam bentuk materi masih dalam bentuk motivasi lisan. Motivasi lisan ini dapat dilakukan dalam bentuk sanjungan dan ucapan terimakasih ketika seluruh guru dan staf mencari keberhasilan kerja. ${ }^{17}$

Berdasarkan pernyataan di atas, dapat disimpulkan bahwa di sekolah ini selalu ada motivasi dalam bentuk ucapan. Terkadang ucapan terimakasih atasan dilakukan ketika ada pertemuan seluruh guru. Misalnya ketika rapat atau pada saat jam istrahat ketika kumpul bersama. Motivasi yang diberikan kepala sekolah yaitu berupa nasehat, dan ucapan selamat jika ada guru atau staf yang telah menyelesaikan studi lanjut.

Uraian di atas diperkuat oleh salah-seorang informan. Adapun pernyataan sebgai berikut:

Terkadang kami sebagai guru mendapatkan ucapan khusus dari kepala sekolah karena kegiatan positif yang telah kami lakukan. Sebagai seorang bawahan ini memberi nilai tersendiri, sebab ini akan memberikan pembeda dengan guru yang lainnya. Selain itu, hal ini juga akan memberikan motivasi bagi kawan-kawan yang lain untuk aktif dan berprestasi dalam bekerja.

Berdasarkan pernyataan di atas, tentunya dapat ditarik kesimpulan bahwa dalam peningkatan guru dan staf di SMA Muhammadiyah Kendari pemimpin juga memberikan motivasi. Adapun motivasi yang diberikan dalam bentuk ucapan lisan, untuk saat ini pemberian motivasi baru sebatas ucapan, untuk pemberian materi dalam bentuk reward belum ada.

\section{Pengawasan Guru dan Tenaga Kependidikan}

Pengawasan adalah usaha untuk dapat mencegah terhadap kemungkinan-kemungkinan penyimpangan terhadap rencana-rencana

\footnotetext{
${ }^{17}$ Lapunda, (Wakil Kepala Sekolah), Wawancara, 27 Agustus 2018
} 
yang telah ditetapkan. Dengan pengawasan diharapkan penyimpangan-penyimpangan yang mungkin terjadi dapat ditekan sehingga kemungkinan timbulnya kerugian yang besar dapat dikurangi atau setidak-tidaknya dapat diperkecil.

Berdasarkan hasil penelitian diperoleh data bahwa dalam pengelolaan pendidikan telah dilakukan pengawasan. Dalam pelaksanaanya pengawasan ini tidak hanya dilakukan oleh kepala sekolah tetapi juga melibatkan semua komponen sekolah dengan maksud agar semua komponen sekolah bertanggunjawab atas keberhasilan peneglolaan pendidikan pada sekolah tersebut.

Penjelasan di atas, sesuai dengan hasil wawancara dengan kepala sekolah bahwa:

Dalam fungsi pengawasan, kepala sekolah melaksanakan fungsi kontrol pelaksanaan kebijakan-kebijakan dan programprogram sekolah kaitannya dengan pengelolaan pendidikan dan pengajaran serta kinerja staf, yang bertujuan agar kesalahan dan penyimpangan dalam pelaksanaan program tidak terjadi, utamanya yang menyangkut masalah pengelolaan yang dibuat sesuai dengan perencanaan dapat diaplikasikan dengan baik. ${ }^{18}$

Dari hasil wawancara sangat jelas bahwa pengelolaan pendidikan melalui pengawasan telah dilakukan oleh kepala sekolah sesuai dengan cara dan komponen pada sekolah tersebut. Pada dasarnya tujuan dari pelaksanaan evaluasi adalah untuk mengetahui sejauh mana keberhasilan program yang telah dibuat. Jika belum tercapai secara maksimal maka dilakukan perbaikan yang berkesinambungan.

Secara umum kegiatan pengawasan di SMA Muhamadiyah Kendari dilakukan oleh kepala sekolah setiap akhir bulan. Adapun bentuk pengawasannya adalah kunjungan kelas dengan melihat kegiatan pembelajaran di kelas. Jika dalam kunjungannya terdapat permasalahan dalam mengajar maka kepala sekolah melakukan diskusi bersama guru yang bersangkutan yang selanjutnya diadakan perbaikan secara berkala. Hal itu berdasarkan hasil wawancara sebagai berikut:

Kepala sekolah selalu melakukan pengawasan secara berkala dalam bentuk kunjungan kelas. Setiap melakukan kunjungan

${ }^{18}$ Taslim, (kepala sekolah), Wawancara, 27 Agustus 2018 
jika ditemukan masalah maka kepala madrasah melakukan diskusi bersama guru yang bersangkutan. Jika masalah serius maka dibicarakan dalam rapat. ${ }^{19}$

Jadi bentuk pengawasan yang dilakukan kepala sekolah adalah melalui kunjungan kelas melihat secara langsung pelaksanaan pembelajaran. Jika ditemukan masalah dalam kunjungan kelas maka kepala sekolah segera membicarakan bersama guru bersangkutan atau kepada forum guru ketika rapat.

\section{Pembahasan}

\section{Pentingnya Peran Kepala Sekolah dalam Pengelolaan Tenaga Pendidik dan Kependidikan}

Dalam menjalankan tugas di sekolah, maka kepala sekolah harus dapat menjalankan perannya, baik sebagai pendidik (edukator), pengelola pendidikan (manager), pelaksana administrasi (administrator), pembina guru (supervisor), pemimpin para guru (leader), pembawa perubahan (inovator), dan pemberi motivasi

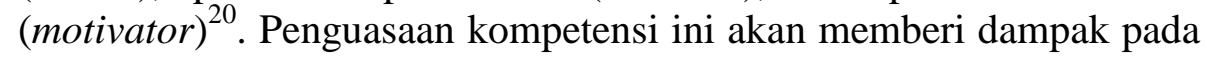
kinerja yang dijalankannya. Untuk lebih jelas diuraikan sebagai berikut:

\section{a. Peran sebagai pendidik}

Pendidik adalah orang yang melakukan pekerjaan mendidik ${ }^{21}$, artinya memberikan latihan dan ajaran mengenai nilai-nilai, akhlak dan kecerdasan pikiran, sehingga pendidikan dapat diartikan sebagai proses pengubahan sikap dan perilaku individu atau kelompok menuju kedewasaan secara optimal. Karena itu, memahami arti kata pendidikan seharusnya lebih mendalam dengan mempelajari keterkaitannya terhadap makna, fungsi, tujuan pendidikan dan bagaimana strategi pelaksanaannya.

Kepala sekolah sebagai edukator harus memahami perbedaan individu yang terindekasi melalui fenomena yang terjadi, seperti:

${ }^{19}$ Jasmani,(Tenaga Pendidik), Wawancara, 23 Juli 2018

${ }^{20}$ De Keizer, H., \& Pringgabayu, D. (2018). Pengaruh Kepemimpinan Kepala Sekolah, Motivasi, dan Budaya Sekolah, Terhadap Kinerja Guru Di SMK ICB Cinta Niaga Kota Bandung. JMBI UNSRAT (Jurnal Ilmiah Manajemen Bisnis dan Inovasi Universitas Sam Ratulangi)., 4(1).

${ }^{21}$ Abdullah, S. (2016). Membangun Kualitas Pendidikan Bermutu Pada Aspek Kompetensi Paedagogik Dan Kompetensi Kepribadian Bagi Seorang Calon Guru. Edukasi, 14(2). 
motivasi, tanggung jawab, latar belakang kehidupan sosial, tingkat kematangan, latar belakang pendidikan. Kondisi tersebut menyebabkan kepala sekolah harus berperan sebagai edukator untuk menanamkan nilai-nilai mental, moral, fisik dan estetika pada diri guru, staf administrasi dan siswa, dengan melakukan tindakan persuasif dan keteladanan ${ }^{22}$.

Kepala sekolah sebagai edukator memiliki tujuh aspek, yaitu: prestasi sebagai guru, kemampuan membimbing guru, kemampuan membimbing siswa, mengembangkan staf, mengikuti perkembangan iptek, dan memberi contoh cara mengajar, melaksanakan bimbingan dan konseling yang baik. Keberhasilan seorang kepala sekolah dalam "melaksanakan peranannya sebagai seorang edukator, akan terlihat pada sejauh mana nilai-nilai moral (disiplin, saling menghargai, saling menghormati, toleransi sesama guru) diimplementasikan dalam kehidupan sekolah" 23

Dalam melakukan fungsinya sebagai edukator, kepala sekolah harus memiliki strategi yang tepat untuk meningkatkan profesionalisme tenaga guru di sekolahnya. Menciptakan iklim sekolah yang kondusif, memberikan nasehat kepada guru dan karyawan, serta melaksanakan model pembelajaran yang menarik. Untuk memahami arti pendidik tidak cukup berpegang pada konotasi yang terkandung dalam definisi pendidik, melainkan harus dipelajari karakteristiknya dengan makna pendidikan, sarana pendidikan dan bagaimana strategi pendidikan itu dilaksanakan ${ }^{24}$.

\section{b. Peran sebagai Manajer}

Seorang kepala sekolah pada hakekatnya adalah guru yang diberi tugas tambahan sebagai pimpinan sekolah ${ }^{25}$. Maka ia masih mempunyai kewajiban untuk melaksanakan profesinya sebagai guru

22 Uriatman, M. (2015). Upaya kepala sekolah dalam meningkatkan kedisiplinan guru. Manajer Pendidikan, 9(6).

${ }^{23}$ Aziz, A. (2015). Peningkatan Mutu Pendidikan. Jurnal Studi Islam. STAI Pancawahana Bangil, 1-13.

${ }^{24}$ Rusmawati, V. (2013). Peran kepemimpinan kepala sekolah dalam upaya meningkatkan disiplin kerja guru pada SDN 018 Balikpapan. Journal Administrasi Negara, 1(2), 395-409.

${ }^{25}$ Manik, E., \& Bustomi, K. (2011). Pengaruh Kepemimpinan Kepala Sekolah, Budaya Organisasi Dan Motivasi Kerja Terhadap Kinerja Guru Pada SMP Negeri 3 Rancaekek. Jurnal Ekonomi, Bisnis \& Entrepreneurship, 5(2), 97-107. 
dengan beban mengajar 6 jam. Di samping itu kepala sekolah harus mengemban tugas lain yang juga sangat penting dalam proses penyelenggaraan pendidikan di sekolah, yaitu sebagai manager pendidikan. Manajer pendidikan sebagai profesi bidang kependidikan memerlukan persyaratan khusus yang harus dipenuhi sebelum melaksanakan tugas yang sesungguhnya.

Agar kepala sekolah dapat melaksanakan tugas dengan baik dan tidak ketinggalan zaman dan perkembangan teknologi, maka sebagai manager pendidikann hendaknya mampu mengembangkan diri secara berkelanjutan, memiliki pengetahuan dan keterampilan melalui peningkatan kualitas dan kemampuan profesional ${ }^{26}$. Seorang manager, kepala sekolah harus disiapkan melalui pendidikan dan latihan manajemen agar dapat memperkuat landasan kemanagerialannya. Apabila tidak disiapkan terlebih dahulu akan berakibat pada buruknya kinerja dalam pelaksanaan tugas sehari-hari sebagai manager pendidikan terutama dalam memberikan layanan kepada lembaga pendidikan yang dikelolanya dan juga kepada masyarakat. Konsekwensinya, pendidikan dan latihan, sertifikasi dan lisensi merupakan syarat bagi seorang manager pendidikan ${ }^{27}$.

Kepala sekolah perlu mengikuti pendidikan dan latihan (diklat) manajemen pendidikan dan mendapat ijazah atau akta untuk dapat menjalankan tugasnya sebagai manager pendidikan yang profesional. Di samping itu, perlu adanya suatu wadah profesional yang dapat menampung para anggota profesi yang bertujuan untuk memperekat basis profesional seorang manager pendidikan ${ }^{28}$.

\section{c. Peran sebagai Administrator}

Tugas kepala sekolah sebagai administrator adalah mengatur dan mengelola kegiatan administrasi sekolah untuk mendukung pelaksanaan pembelajaran yang efektif. Sutisna menyatakan, bahwa: "Administrasi mungkin dapat didefinisikan sebagai proses yang

${ }^{26}$ Oktarina, N. (2009). Profesionalisme Kepala Sekolah Dalam Pengelolaan Pendidikan Untuk Mewujudkan Sekolah Efektif. Dinamika Pendidikan, 4(1).

${ }^{27}$ Rosyadi, Y. I., \& Pardjono, P. (2015). Peran kepala sekolah sebagai manajer dalam meningkatkan mutu pendidikan di smp 1 cilawu garut. Jurnal Akuntabilitas Manajemen Pendidikan, 3(1), 124-133.

28 Ratmawati, T. (2012). Kualifikasi, Intensitas Diklat, Lingkungan, Motivasi Kerja, dan Kompetensi Kepala Sekolah. Jurnal Ilmu Pendidikan Universitas Negeri Malang, 17(6). 
membuat kegiatan-kegiatan terselenggara dengan efisien bersama dengan atau melalui orang lain. Proses tersebut menunjuk kepada membuat keputusan, merencanakan, memimpin, mengkoordinasikan dan mengawasi kegiatankegiatan untuk mencapai tujuan-tujuan organisasi". ${ }^{29}$

Berkaitan dengan perilaku manusia dalam suatu organisasi yang menentukan kelangsungan suatu proses pelaksanaan tugas dalam administrasi pendidikan, mengungkapkan bahwa "Administrasi pendidikan sebagai suatu proses sistem perilaku. Konsep ini mengandung arti bahwa dalam penyelenggaraan pendidikan terjadilah suatu proses interaksi antar manusia dalam sistem yang terarah dan terkoordinir dalam mencapai tujuan" ${ }^{30}$.

Kepala sekolah sebagai administrator memiliki hubungan yang sangat erat dengan berbagai aktivitas pengelolaan administrasi yang sifatnya mencatat, menyusun dan mendokumentasikan seluruh program sekolah ${ }^{31}$. Mulyasa mengatakan kepala sekolah sebagai seorang adminitrator harus memiliki kemampuan untuk mengelola adminsitrasi personalia, keuangan, kurikulum, siswa, sarana dan hubungan masyarakat (humas) ${ }^{32}$.

\section{d. Peran sebagai Supervisor}

Sebagai supervisor, tugas seorang kepala sekolah adalah melakukan supervisi terhadap guru yang mengajar sebagai kegiatan utama di sekolah. Kegiatan melaksanakan supervisi terhadap guru penting dilaksanakan oleh kepala sekolah dalam upaya peningkatan kualitas kinerjanya melalui peningkatan kemampuan profesionalnya. Alasan lain pentingnya supervisi pengajaran saat ini adalah kondisi

29 Sutisna, O. (1983). Administrasi Pendidikan: Dasar teoritis untuk praktek profesional. Angkasa, Bandung.

${ }^{30}$ Pendidikan, T. D. J. A. (1989). Administrasi Pendidikan. FIP IKIP Malang, Malang.

31 Fitrah, M. (2017). Peran kepala sekolah dalam meningkatkan mutu pendidikan. Jurnal Penjaminan Mutu, 3(1), 31-42.

${ }^{32}$ Mulyasa, E. (2004). Menjadi Kepala Guru yang Profesional. Bandung: Remaja Rodaskarya. 
kemampuan profesional guru yang masih memprihatinkan dan secara langsung berpengaruh pada mutu lulusan ${ }^{33}$.

Kepala sekolah sebagai supervisor memiliki tanggung jawab dalam membina guru dan staf tata usaha di sekolah, agar mampu mengatasi berbagai permasalahan dalam konteks pembelajaran. Sehingga mereka mampu menyesuaikan dengan perkembangan yang terjadi serta mampu mengaktualisasikan diri dalam melaksanakan tugas sebagai guru profesional. Guru adalah ujung tombak yang sangat menentukan keberhasilan pencapaian tujuan pendidikan di sekolah $^{34}$.

Peran kepala sekolah sebagai supervisor diharapkan dapat membantu rekan-rekan guru secara profesional untuk mengatasi berbagai persoalan proses belajar mengajar. Kedudukannya sebagai supervisor telah menempatkan kepala sekolah pada posisi penting dalam pembinaan dan pengembangan mutu kinerja guru, khususnya dalam meningkatkan efektivitas pembelajaran di sekolah ${ }^{35}$.

Keberhasilan guru dalam proses pembelajaran dapat membantu memelihara kewibawaan kepala sekolah, maka tidaklah berlebihan jika dikatakan dalam kepemimpinannya kepala sekolah harus mementingkan kebersamaan dengan membina hubungan baik dengan guru dan staf administrasi ${ }^{36}$. Mereka semua adalah mitra kerja kepala sekolah dalam meraih keberhasilan pendidikan di sekolah. Jika kepala sekolah tidak dapat menjalinkan kebersamaan yang baik dengan guru-guru sangat sulit bagi kepala sekolah untuk menggerakkan mereka kearah yang diinginkan ${ }^{37}$.

${ }^{33}$ Maghfiroh, A. (2010). Peran kepala sekolah sebagai supervisor dalam peningkatan mutu guru PAI di SMP Nasima Semarang (Doctoral dissertation, IAIN Walisongo).

34 Ariana, I. W., Dantes, N., \& Lasmawan, M. P. P. I. W. (2015). Kontribusi supervisi kepala sekolah, motivasi berprestasi dan komitmen kerja terhadap kinerja guru di gugus sekolah VIII Kecamatan Abang (Doctoral dissertation, Ganesha University of Education).

35 Zakso, A., \& Radiana, U. (2013). Pelaksanaan Supervisi Akademik Pengawas Sekolah Sebagai Upaya Peningkatan Profesionalisme Guru SMP Negeri 1 Bengkayang. Jurnal Pendidikan dan Pembelajaran, 2(3).

${ }^{36}$ Kependidikan, D. T., JENDERAL, D., KEPENDIDIKAN, P. M. P. D. T., \& NASIONAL, D. P. (2008). Kriteria dan Indikator Keberhasilan Pembelajaran.

${ }^{37}$ Iskandar, U. (2013). Kepemimpinan kepala sekolah dalam peningkatan kinerja guru. Jurnal Visi Ilmu Pendidikan, 10(1). 


\section{e. Peran sebagai Motivator}

Motif dapat diartikan sebagai suatu dorongan atau kekuatan yang menyebabkan seseorang melakukan sesuatu ${ }^{38}$. Dengan kata lain, motif merupakan suatu driving force yang menggerakkan seseorang untuk bertingkah laku guna mencapai suatu tujuan yang diinginkan ${ }^{39}$. Motivasi lebih ditekankan kepada pemberian atau pemunculan motif yang merupakan suatu kekuatan pendorong yang menggerakkan manusia untuk bertingkah laku guna mencapai tujuan ${ }^{40}$.

Ada tiga macam kemampuan yang harus dimiliki oleh kepala sekolah agar dapat melaksanakan tugasnya sebagai motivator yang baik yaitu: kemampuan mengatur lingkungan kerja (fisik), kemampuan mengatur suasana kerja (non fisik) dan kemampuan menetapkan prinsip penghargaan dan hukuman Debdiknas,. Pemberian motivasi dapat dilakukan secara langsung maupun tidak langsung kepada guru/karyawan. Motivasi yang langsung dapat diberikan berupa pujian, penghargaan, tunjangan hari raya, bonus bintang jasa dan sejenisnya. Secara tidak langsung motivasi dapat diberikan berupa pemberian berbagai fasilitas yang dibutuhkan guna meningkatkan efektivitas kerja.

Kepala sekolah sebagai motivator, harus mampu memiliki strategi yang tepat untuk memberikan motivasi kepada para guru dalam melakukan berbagai tugas dan fungsinya ${ }^{41}$. Motivasi ini dapat diberikan kepada para guru dengan melalui pengaturan lingkungan fisik, pengaturan suasana kerja, disiplin, dorongan, panghargaan, penyedian berbagai sumber belajar dan sebagainya yang dapat merangsang guru untuk lebih aktif dan kreatif dalam mengajar di sekolah. Kepala sekolah harus mempunyai harapan yang tinggi untuk meningkatkan kualitas pendidikan, komitmen dan motivasi yang kuat untuk meningkatkan mutu sekolah secara optimal. Guru yang

${ }^{38}$ Prihartanta, W. (2015). Teori-teori motivasi. Jurnal Adabiya, 1(83), 1-14.

${ }^{39}$ Medina, Z., Christin, M., \& Malau, R. M. U. (2016). Motif Pengguna Aplikasi Line Webtoon (Studi Deskriptif Kuantitatif pada Pengikut Akun Official Line Webtoon ID). eProceedings of Management, 3(3).

40 Effendi, R. (2015). Hubungan Budaya Organisasi dan Penghargaan terhadap Motivasi Karyawan: Studi Kausal terhadap Karyawan Universitas Megoupak Tulang Bawang. Jurnal Manajemen dan Keuangan, 10(2).

${ }^{41}$ Rusmawati, V. (2013). Peran kepemimpinan kepala sekolah dalam upaya meningkatkan disiplin kerja guru pada SDN 018 Balikpapan. Journal Administrasi Negara, 1(2), 395-409. 
memiliki komitmen dan harapan yang tinggi bahwa siswa dapat mencapai prestasi yang optimal, meskipun dengan segala keterbatasan sumber daya pendidikan yang ada di sekolah. Dalam pada itu, siswa juga termotivasi untuk secara sadar meningkatkan diri dalam mencapai prestasi sesuai dengan bakat dan kemampuan yang dimiliki. Harapan tinggi dari berbagai dimensi sekolah merupakan faktor dominan yang menyebabkan sekolah selalu dinamis untuk melakukan perbaikan secara berkelanjutan ${ }^{42}$.

\section{f. Peran sebagai Inovator}

Sebagai agen pembaharu terhadap lembaga pendidikan yang dipimpinnya, seorang kepala sekolah sangat dituntut kesiapan untuk selalu berperan dalam setiap situasi kerja menuju perubahan, karena perubahan itu sendiri diperlukan sebagai media dalam rangka pemecahan masalah yang bertujuan menciptakan kondisi yang lebih baik. Pembaharuan dapat terjadi dalam bentuk yang direncanakan secara matang sebagai gagasan dan rekayasa khusus yang dilakukan para pemimpin $^{43}$.

Di sisi lain, ada pembaharuan yang terjadi tanpa direncanakan terlebih dahulu, tapi muncul secara tiba-tiba akibat ketidakpuasan dari anggota organisasi terhadap situasi. Karena itu, kepala sekolah sebagai inovator dapat berperan dalam mewujudkan perubahan nilai-nilai, sikap, pola pikir, perilaku intelektual, keterampilan dan wawasan para siswa sesuai dengan tujuan pendidikan itu sendiri. Sebagai inovator pendidikan kepala sekolah dituntut untuk secara terus menerus melaksanakan inovasi dalam pembelajaran sehingga mutu pendidikan dapat ditingkatkan ${ }^{44}$.

Manajemen tenaga pendidik secara garis besar mencakup tujuh komponen. Tujuh komponen ini dilaksanakan secara urut, tertib, dan

${ }^{42}$ Muhibbin, S. (2010). Psikologi pendidikan dengan pendekatan baru. Bandung: PT Remaja Rosdakarya.

${ }^{43}$ Purwanti, E. (2017). Peran Komite Sekolah Dan Kepala Sekolah Dalam Meningkatkan Mutu Pendidikan Di Mi Muhammadiyah Kedungwuluh Lor (Doctoral Dissertation, Universitas Muhammadiyah Purwokerto).

${ }^{44}$ Rahman, A. (2010). Kepala Sekolah Sebagai Inovator dalam Pendidikan (Dalam Rangka Pelaksanaan Manajemen Berbasis Sekolah). -. 
berkesinambungan sehingga harus melalui tahapan-tahapan yang sudah ditentukan ${ }^{45}$. Ketujuh komponen tersebut adalah:

a. Perencanaan Tenaga Pendidik

Perencanaan pengadaan guru merupakan kegiatan menentukan kebutuhan pegawai, baik secara kuantitatif maupun kualitatif untuk sekarang dan masa depan ${ }^{46}$. Masa lampau telah mengantarkan kondisi sekarang sehingga bisa dijadikan acuan untuk merencanakan masa depan berdasarkan potensi yang ada. Sepanjang situasi yang dihadapi di masa lampau yang telah mengantarkan kondisi masa sekarang ini dapat dijadikan acuan yang sama untuk memprediksi masa depan. Tetapi, jika situasinya sama sekali lain maka dibutuhkan kejelian membaca situasi dalam menyusun perencanaan ${ }^{47}$. Perubahan inilah yang dewasa ini sering dihadapi oleh para perencana sehingga dibutuhkan jurus-jurus jitu sebagai upaya antisipasi sedini mungkin.

\section{b. Rekrutmen Tenaga Pendidik}

Rekrutmen Guru/tenaga pendidik merupakan kegiatan untuk memenuhi kebutuhan pegawai pada suatu lembaga, baik jumlah maupun kualitasnya. Gorton mangatkan bahwa : Tujuan rekrutmen pegawai adalah menyediakan calon pegawai yang betul-betul baik (surplus of candidates) dan paling memenuhi kualifikasi (most qualified and outstanding individuals) untuk sebuah posisi ${ }^{48}$. Pada dasarnya kegiatan rekrutmen tenaga pendidik itu sangat penting, sebab selain akan menemukan pengajar yang lebih profesional maka akan diperoleh pula guru yang kompeten dalam bidangnya.

Sebagaimana disebutkan oleh M. Daryanto, syarat-syarat tenaga pendidk adalah: ${ }^{49}$
a. Kepribadian
b. Kesetiaan
c. Kesehatan badan
d. Kecerdasan

${ }^{45}$ Mulyasa, M. B. S. (2004). Konsep Strategi dan Implementasi, Bandung: PT. Remaja Rosdakarya Offset, Cet. V.

${ }^{46}$ ibid

${ }^{47}$ Suwantoro, S. (2019). Manajemen Dan Kepemimpinan Pendidikan Islam Berbasis Entrepreneurship. JALIE; Journal of Applied Linguistics and Islamic Education, 2(1), 127-146.

\footnotetext{
${ }^{48}$ ibid

${ }^{49}$ Daryanto, H. M. (1998). Administrasi pendidikan. PT Rineka Cipta.
} 
e. Kemampuan

f. Ketangkasan

g. Dan syarat-syarat lain yang khusus bagi sesuatu jabatan negeri yang telah ditetapkan oleh pemerintah.

c. Pengembangan dan Pembinaan Tenaga Pendidik

Pendidik sebagai individu membutuhkan pembinaan dan pengembangan untuk memperbaiki dan meningkatkan profesional termasuk dalam tugasnya. Pembinaan lebih berorientasi pencapaian standar minimal, yaitu disarankan untuk dapat melakukan pekerjaan/tugasnya selain berorientasi pada perkembangan karier para guru, termasuk upaya manajer untuk memfasilitasi mereka suapay bisa mencapai jabatan atau status yang lebih tinggi, maka pengembangan juga diarahkan agar guru menjadi lebih profesional ${ }^{50}$.

\section{d. Promosi dan Mutasi}

Promosi (kenaikan pangkat) merupakan perubahan kedudukan yang bersifat vertikal, sehingga bermplikasi pada wewenang tanggungjawab, dan penghasilan ${ }^{51}$. Di Indonesia, untuk guru promosi atau pengangkatan pertama biasanya diangkat sebagai calon PNS dengan masa percobaan satu atau dua tahun, kemudian ia mengikuti latihan prajabatan, dan setelah lulus diangkat menjadi pegawai negeri sipil penuh. Setalah pengangkatan pegawai, kegiatan selanjutnya adalah penempatan atau penugasan ${ }^{52}$. Jadi pada dasarnya pengangkatan tenaga guru tidak asal diangkat akan tetapi harus melewati prosedur seperti terlebih dahulu menjadi calon PNS selama dua tahun dan selanjutnya diangkat penuh menjadi PNS.

Sedangkan mutasi adalah pemindahan pegawai dari suatu jabatan kejabatan lain. Pemindahan ini lebih bersifat horizontal sehingga tidak berimplikasi pada penghasilan ${ }^{53}$. Mutasi bisa berkonotasi positif namun juga kadang berkonotasi negatif. Jika

${ }^{50}$ Qomar, M. (2013). Manajemen Pendidikan Islam, (Malang: PT Gelora Aksara Pratama.

${ }^{51}$ Iskandar, C. (2015). Pengaruh Prestasi Kerja Dan Kenaikan Pangkat Terhadap Promosi Jabatan Pegawai Negeri Sipil Di Lingkungan Pemerintah Kabupaten Sumenep (Studi Pada Bkpp Kabupaten Sumenep). Public Corner, 7(1).

${ }^{52}$ Prasojo, D. B. (2013). Pengaruh Pemberian Kompensasi Non Finansial Terhadap Kinerja Guru SMP Negeri Se Kecamatan Bantul. Hanata Widya.

${ }^{53}$ Mujamil Qomar, Op.Cit., h. 137 
mutasi dilakukan sebagai penyegaran organisasi, maka makna konotasinya positif. Namun jika pemindahan itu karena suatu kasus tertentu maka konotasinya terkesan sebagai langkah pembuangan.

e. Pemberhentian Tenaga Pendidik

Ada batas tertentu dan ketentuan dan dimiliki pegawai sehingga suatu ketika harus diberhentikan. Pemberhentian oleh dinas atau pemerintah dapat dilakukan dengan beberapa alasan berikut ${ }^{54}$ :

1) Pegawai yang bersangkutan tidak cakap dan tidak memiliki kemampuan untuk melaksanakan tugas-tugasnya dengan baik;

2) Perampingan atau penyederhanaan organisasi;

3) Peremajaan, biasanya pegawai yang telah berusia 60 tahun dan berhak pensiun harus diberhentikan dalam jangka waktu satu tahun;

4) Tidak sehat jasmani dan rohani sehingga tidak dapat melaksanakan tugasnya dengan baik;

5) Melakukan pelanggaran tindak pidana sehingga dihukum penjara atau kurungan;

6) Melanggar sumpah atau janji pegawai negeri sipil.

\section{f. Kompensasi Tenaga Pendidik}

Kompensasi adalah balas jasa atau juga disebut denagn reward yang diberikan lembaga pendidikan kepada guru, yang dapat dinilai dengan uang dan memiliki kecenderunagn diberikan secara tetap. Pemberian kompensasi selain dalam bentuk gaji, dapat juga berupa tunjangan, fasilitas perumahan, kendaraan dan lain-lain ${ }^{55}$.

\section{g. Penilaian Tenaga Pendidik}

Penilaian tenaga pendidik ini difokuskan pada prestasi individu dan peran sertantanya dalam kegiatan sekolah. Penilaian ini tidak hanya penting bagi sekolah, tetapi juga pegawai itu sendiri. Bagi para pegawai, penilaian berguna sebagai umpan balik berbagai hal, seperti kemampuan, keletihan, kekurangan dan potensi yang pada gilirannya bermanfaat untuk menentukantujuan, jalur, dan

\footnotetext{
${ }^{54}$ Bachtiar, M. Y. (2016). Pendidik dan Tenaga Kependidikan. Publikasi Pendidikan, 6(3)

${ }^{55}$ Mutakin, T. Z. (2015). Pengaruh kompetensi, kompensasi, dan latar belakang terhadap kinerja guru. Formatif: Jurnal Ilmiah Pendidikan MIPA, 3(2).
} 
pemngembangan karier. Bagi sekolah, hasil penilaian prestasi kerja tenaga pendidik sanagat penting dalam pengambilan keputusan berbagai hal, sperti identifikasi kebutuahn program sekolah penerimaan, pemilihan, pengenalan, penempatan, promosi, sistem imbalan, dan aspek lain dari keseluruhan proses efektif sumber daya manusia $^{56}$.

\section{Optimalisasi Pengelolaan Tenaga Pendidik}

Tenaga pendidik merupakan tenaga-tenaga (personil) yang terlibat langsung di dalam lembaga pendidikan. Pendidik tersebut memiliki wawasan pendidikan (memahami falsafah dan ilmu pendidikan), dan melakukan kegiatan pelaksanaan pendidikan (mikro atau makro) atau penyelenggaraan pendidikan ${ }^{57}$.

Ahmad Tafsir yang dikemukakan oleh Sulistiyorini di dalam bukunya, pendidik dalam islam adalah orang-orang yang bertanggungjawab terhadap perkembangan anak didik dengan mengupayakan perkembangan seluruh potensi anak didik, baim potensi efektif, potensi kognitif, maupun potensi pikomotorik ${ }^{58}$.

Pada hakekatnya yang dimaksudkan dengan tenaga pendidik pada uraian di atas adalah guru. Guru selaku pengelola pendidikan mempunyai peranan sangat penting, karena bersentuhan langsung dengan anak didik. Oleh karenanya harus memiliki beberapa kriteria untuk untuk menjadi guru yang baik, antara lain: telah dijelaskan dalam undang-undang guru dan dosen No. 14 Tahun 2005 pasal 8 sebagai berikut: "Guru wajib memiliki kualifikasi akademika kompetensi, sertifikasi pendidik, sehat jasmani dan rohani, serta memiliki kemampuan untuk mewujudkan tujuan pendidikan nasional" $"$.

\footnotetext{
${ }^{56}$ Suhandani, D., \& Julia, J. (2014). Identifikasi Kompetensi Guru Sebagai Cerminan Profesionalisme Tenaga Pendidik Di Kabupaten Sumedang (Kajian Pada Kompetensi Pedagogik). Mimbar Sekolah Dasar, 1(2), 128-141.

${ }^{57}$ Bakar, A. (2011). Supervisi Pendidikan Agama Islam (Pembinaan Guru Agama Madrasah/Sekolah). Sosial Budaya, 8(1), 1-24.

${ }^{58}$ Qa, D. (2015). Peran Kepala Madrasah Dalam Meningkatkan Profesionalisme Guru Di Man Tulungagung 1.

${ }^{59}$ RI, K. P. N. (2006). Undang-Undang RI No. 14 Tahun 2005 tentang Guru dan Dosen.
} 


\section{Penguatan Kompetensi Tenaga Pendidik dan Kependidikan}

Lahirnya UU No. 14 Tahun 2005 merupakan salah satu usaha untuk meningkatkkan mutu guru, sekaligus diharapkan dapat meningkatkan mutu pendidikan di Indonesia ${ }^{60}$. Di dalam UU ini diamanatkan bahwa guru wajib memiliki kualifikasi akademik, kompetensi, sertifikat pendidik, sehat jasmani dan rohani, serta memiliki kemampuan untuk mewujudkan tujuan pendidikan nasional. Kebijakan prioritas dalam rangka pemberdayaan guru saat ini adalah meningkatkan kualifikasi, peningkatan kompetensi, sertifikasi guru, pengembangan karir, penghargaan dan perlindungan, perencanaan kebutuhan guru, tunjangan guru, dan maslahat tambahan. Demikian pula dengan tenaga kependidikan yang secara bersama memberi sumbangan kemajuan lembaga pendidikan ${ }^{61}$.

\section{Kesimpulan}

Guru dan tenaga kependidikan merupakan komponen penting dalam penyelenggaraan sekolah, sehingga menjadi aspek penting dalam penilaian sekolah yang baik. Kepala sekolah mesti memiliki kesadaran penuh untuk melakukan pengelolalan guru maupun tenaga kependidikan dalam rangka mencapai kemajuan sekolah. SMA Muhammadiyah kendari menunjukkan bahwa pengelolaan guru dan tenaga kependidikan yang memenuhi standar dapat mengantarkan sekolah bersaing dengan sekolah-sekolah sederajat.

${ }^{60}$ Fahdini, R., Mulyadi, E., Suhandani, D., \& Julia, J. (2014). Identifikasi Kompetensi Guru sebagai Cerminan Profesionalisme Tenaga Pendidik di Kabupaten Sumedang. Mimbar Sekolah Dasar, 1(1), 33-42.

${ }^{61}$ Noor, I. H. (2013). Efektivitas Perubahan Lembaga Pendidikan Tenaga Kependidikan (LPTK)/Institut Keguruan dan Ilmu Pendidikan (IKIP) Menjadi Universitas. Jurnal Pendidikan dan Kebudayaan, 19(3), 382-396. 


\section{Daftar Pustaka}

Abdullah, S. (2016). Membangun Kualitas Pendidikan Bermutu Pada Aspek Kompetensi Paedagogik Dan Kompetensi Kepribadian Bagi Seorang Calon Guru. Edukasi, 14(2).

Ariana, I. W., Dantes, N., \& Lasmawan, M. P. P. I. W. (2015). Kontribusi supervisi kepala sekolah, motivasi berprestasi dan komitmen kerja terhadap kinerja guru di gugus sekolah VIII Kecamatan Abang (Doctoral dissertation, Ganesha University of Education).

Aziz, A. (2015). Peningkatan Mutu Pendidikan. Jurnal Studi Islam. STAI Pancawahana Bangil, 1-13.

Bachtiar, M. Y. (2016). Pendidik dan Tenaga Kependidikan. Publikasi Pendidikan, 6(3).

Baharun, H. (2018). Peningkatan kompetensi guru melalui sistem kepemimpinan kepala madrasah. At-Tajdid: Jurnal Ilmu Tarbiyah, 6(1), 1-26.

Bakar, A. (2011). Supervisi Pendidikan Agama Islam (Pembinaan Guru Agama Madrasah/Sekolah). Sosial Budaya, 8(1), 1-24.

Burhan, B. (2007). Penelitian Kualitatif: Komunikasi, Ekonomi, Kebijakan Publik, dan Ilmu Sosial Lainnya. Jakarta: Prenada Media Group.

Daryanto, H. M. (1998). Administrasi pendidikan. PT Rineka Cipta.

De Keizer, H., \& Pringgabayu, D. (2018). Pengaruh Kepemimpinan Kepala Sekolah, Motivasi, dan Budaya Sekolah, Terhadap Kinerja Guru Di SMK ICB Cinta Niaga Kota Bandung. JMBI UNSRAT (Jurnal Ilmiah Manajemen Bisnis dan Inovasi Universitas Sam Ratulangi)., 4(1).

Effendi, R. (2015). Hubungan Budaya Organisasi dan Penghargaan terhadap Motivasi Karyawan: Studi Kausal terhadap Karyawan Universitas Megoupak Tulang Bawang. Jurnal Manajemen dan Keuangan, 10(2).

Fahdini, R., Mulyadi, E., Suhandani, D., \& Julia, J. (2014). Identifikasi Kompetensi Guru sebagai Cerminan Profesionalisme Tenaga Pendidik di Kabupaten Sumedang. Mimbar Sekolah Dasar, 1(1), 33-42.

Fitrah, M. (2017). Peran kepala sekolah dalam meningkatkan mutu pendidikan. Jurnal Penjaminan Mutu, 3(1), 31-42. 
Gunawan, I. (2013). Metode penelitian kualitatif. Jakarta: Bumi Aksara.

Hendri, E. (2010). Guru berkualitas: profesional dan cerdas emosi. Jurnal saung guru, 1(2), 1.

Iskandar, U. (2013). Kepemimpinan kepala sekolah dalam peningkatan kinerja guru. Jurnal Visi Ilmu Pendidikan, 10(1).

Iskandar, C. (2015). Pengaruh Prestasi Kerja Dan Kenaikan Pangkat Terhadap Promosi Jabatan Pegawai Negeri Sipil Di Lingkungan Pemerintah Kabupaten Sumenep (Studi Pada Bkpp Kabupaten Sumenep). Public Corner, 7(1).

Kependidikan, D. T., JENDERAL, D., KEPENDIDIKAN, P. M. P. D. T., \& NASIONAL, D. P. (2008). Kriteria dan Indikator Keberhasilan Pembelajaran.

Maghfiroh, A. (2010). Peran kepala sekolah sebagai supervisor dalam peningkatan mutu guru PAI di SMP Nasima Semarang (Doctoral dissertation, IAIN Walisongo).

Manik, E., \& Bustomi, K. (2011). Pengaruh Kepemimpinan Kepala Sekolah, Budaya Organisasi Dan Motivasi Kerja Terhadap Kinerja Guru Pada SMP Negeri 3 Rancaekek. Jurnal Ekonomi, Bisnis \& Entrepreneurship, 5(2), 97-107.

Medina, Z., Christin, M., \& Malau, R. M. U. (2016). Motif Pengguna Aplikasi Line Webtoon (Studi Deskriptif Kuantitatif pada Pengikut Akun Official Line Webtoon ID). eProceedings of Management, 3(3).

Moleong, J. Lexy. 2014, Metodologi Penelitian Kualitatif, Bandung: PT. Remaja Rosdakarya.

Muhibbin, S. (2010). Psikologi pendidikan dengan pendekatan baru. Bandung: PT Remaja Rosdakarya.

Mulyasa, E. (2004). Menjadi Kepala Guru yang Profesional. Bandung: Remaja Rodaskarya.

Mulyasa, M. B. S. (2004). Konsep Strategi dan Implementasi, Bandung: PT. Remaja Rosdakarya Offset, Cet. V.

Mutakin, T. Z. (2015). Pengaruh kompetensi, kompensasi, dan latar belakang terhadap kinerja guru. Formatif: Jurnal Ilmiah Pendidikan MIPA, 3(2).

Noor, I. H. (2013). Efektivitas Perubahan Lembaga Pendidikan Tenaga Kependidikan (LPTK)/Institut Keguruan dan Ilmu Pendidikan (IKIP) Menjadi Universitas. Jurnal Pendidikan dan Kebudayaan, 19(3), 382-396. 
Oktarina, N. (2009). Profesionalisme Kepala Sekolah Dalam Pengelolaan Pendidikan Untuk Mewujudkan Sekolah Efektif. Dinamika Pendidikan, 4(1).

Pendidikan, T. D. J. A. (1989). Administrasi Pendidikan. FIP IKIP Malang, Malang.

Prasojo, D. B. (2013). Pengaruh Pemberian Kompensasi Non Finansial Terhadap Kinerja Guru SMP Negeri Se Kecamatan Bantul. Hanata Widya.

Prihartanta, W. (2015). Teori-teori motivasi. Jurnal Adabiya, 1(83), 114.

Purwanti, E. (2017). Peran Komite Sekolah Dan Kepala Sekolah Dalam Meningkatkan Mutu Pendidikan Di Mi Muhammadiyah Kedungwuluh Lor (Doctoral Dissertation, Universitas Muhammadiyah Purwokerto).

Qa, D. (2015). Peran Kepala Madrasah Dalam Meningkatkan Profesionalisme Guru Di Man Tulungagung 1.

Qomar, M. (2013). Manajemen Pendidikan Islam, (Malang: PT Gelora Aksara Pratama.

Rahman, A. (2010). Kepala Sekolah Sebagai Inovator dalam Pendidikan (Dalam Rangka Pelaksanaan Manajemen Berbasis Sekolah).

Ratmawati, T. (2012). Kualifikasi, Intensitas Diklat, Lingkungan, Motivasi Kerja, dan Kompetensi Kepala Sekolah. Jurnal Ilmu Pendidikan Universitas Negeri Malang, 17(6).

RI, K. P. N. (2006). Undang-Undang RI No. 14 Tahun 2005 tentang Guru dan Dosen.

Rosyadi, Y. I., \& Pardjono, P. (2015). Peran kepala sekolah sebagai manajer dalam meningkatkan mutu pendidikan di smp 1 cilawu garut. Jurnal Akuntabilitas Manajemen Pendidikan, 3(1), 124133.

Rusmawati, V. (2013). Peran kepemimpinan kepala sekolah dalam upaya meningkatkan disiplin kerja guru pada SDN 018 Balikpapan. Journal Administrasi Negara, 1(2), 395-409.

Setiyati, S. (2014). Pengaruh kepemimpinan kepala sekolah, motivasi Kerja, dan budaya sekolah terhadap kinerja guru. Jurnal Pendidikan Teknologi dan Kejuruan, 22(2), 200-206.

Sugiyono. (2008). Metode penelitian pendidikan:(pendekatan kuantitatif, kualitatif dan $R \& D$ ). Alfabeta. 
Suhandani, D., \& Julia, J. (2014). Identifikasi Kompetensi Guru Sebagai Cerminan Profesionalisme Tenaga Pendidik Di Kabupaten Sumedang (Kajian Pada Kompetensi Pedagogik). Mimbar Sekolah Dasar, 1(2), 128-141.

Sukmadinata, S. N. (2005). Metode Penelitia. Bandung: PT Remaja Rosdakarya.

Surya, P. (2012). Peran penting tenaga administrasi sekolah dalam penguatan budaya sekolah untuk implementasi pendidikan karakter. Online),(staffnew. uny. ac. id/upload/198111112009121001/penelitian/makalah+ $I K A+$ 2012. pdf).

Sutisna, O. (1983). Administrasi Pendidikan: Dasar teoritis untuk praktek profesional. Angkasa, Bandung.

Suwantoro, S. (2019). Manajemen Dan Kepemimpinan Pendidikan Islam Berbasis Entrepreneurship. JALIE; Journal of Applied Linguistics and Islamic Education, 2(1), 127-146.

Uriatman, M. (2015). Upaya kepala sekolah dalam meningkatkan kedisiplinan guru. Manajer Pendidikan, 9(6).

Zakso, A., \& Radiana, U. (2013). Pelaksanaan Supervisi Akademik Pengawas Sekolah Sebagai Upaya Peningkatan Profesionalisme Guru SMP Negeri 1 Bengkayang. Jurnal Pendidikan dan Pembelajaran, 2(3). 